IRA-International Journal of Education \&

Multidisciplinary Studies

ISSN 2455-2526; Vol.15, Issue 02 (May 2019)

Pg. no. 62-71.

Institute of Research Advances

http://research-advances.org/index.php/IJEMS

\title{
Monitoring Pupils' Academic Performance at Home through Parental Participation in Educational Activities: Focus on Public Primary Schools in Ainabkoi Sub-County
}

\author{
Petrolina Kaptich ${ }^{1}$, Henry Kiptiony Kiplangat ${ }^{2 \#}$, Jennifer Munyua ${ }^{3}$ \\ ${ }^{1}$ Catholic University of Eastern Africa, Nairobi, Kenya \\ ${ }^{2}$ Kabarak University, P.O. Box Private Bag - 20157 Kabarak, Kenya \\ ${ }^{3}$ Catholic University of Eastern Africa, P.O. Box 62157-00200, City Square Nairobi, Kenya
}

\# corresponding author.

Type of Work: Peer Reviewed

DOI: http://dx.doi.org/10.21013/jems.v15.n2.p2

How to cite this paper:

Kaptich, P., Kiplangat, H.K., Munyua, J. (2019). Monitoring Pupils' Academic Performance at Home through Parental Participation in Educational Activities: Focus on Public Primary Schools in Ainabkoi Sub-County. IRA International Journal of Education and Multidisciplinary Studies (ISSN 2455-2526), 15(2), 62-71.doi: http://dx.doi.org/10.21013/jems.v15.n2.p2

(C) Institute of Research Advances.

This work is licensed under a Creative Commons Attribution-Non Commercial 4.0 International License subject to a proper citation to the publication source of the work.

Disclaimer: The scholarly papers as reviewed and published by the Institute of Research Advances (IRA) are the views and opinions of their respective authors and are not the views or opinions of the IRA. The IRA disclaims of any harm or loss caused due to the published content to any party.

Institute of Research Advances is an institutional publisher member of Publishers International Linking Association Inc. (PILA-CrossRef), USA. The institute is an institutional signatory to the Budapest Open Access Initiative, Hungary advocating the open access of scientific and scholarly knowledge. The Institute is a registered content provider under Open Access Initiative Protocol for Metadata Harvesting (OAI-PMH).

The journal is indexed \& included in WorldCat Discovery Service (USA), CrossRef Metadata Search (USA), WorldCat (USA), OCLC (USA), Open J-Gate (India), EZB (Germany) Scilit (Switzerland), Airiti (China), Bielefeld Academic Search Engine (BASE) of Bielefeld University, Germany, PKP Index of Simon Fraser University, Canada. 


\begin{abstract}
Poor performance in Kenya Certificate of Primary Education Examinations has often been attributed to a lack of parental participation in children's academics. The claim that parents are not supportive of their children, especially at home, therefore holds water as researchers have established that parent involvement with their children's homework could have an influence on their academic performance. This paper draws our attention to a study conducted to investigate the influence of parental involvement in school work on pupils' academic performance in public primary schools in Ainabkoi Sub County, Kenya. Joyce Epstein's framework of six types of parent involvement guided the study adopting the ex-post facto research design. Targeting 2404 Class 8 pupils and 61 class teachers in Ainabkoi Sub County, the authors drew a sample of 331 class eight pupils through stratified simple random sampling while census approach was employed to involve all the class teachers in the selected schools. The modes of data collection used were questionnaire and interview schedule whose validity was ensured through pilot study and reliability by test-retest technique. Quantitative data was then analyzed using descriptive and inferential statistics in the form of percentages, means and chi-square, to test the study hypothesis. It was found out that parental participation in educational activities at home $\left(X^{2}=8.196 ; p=0.017\right)$ had a positive and significant influence on academic performance in public primary schools. Qualitative data was presented thematically. The study recommends that parents should provide their children with the required learning materials, such as supplementary reading complements to improve their academic performance.
\end{abstract}

Keywords: Educational activities, Home, Primary Schools, Ainabkoi, Parent's participation, Parental involvement

\title{
Introduction
}

Education is an essential tool for societal development. The more educated the people of a society are the more civilized and well-disciplined the society might be. Mainly, family and parents, in particular, have the responsibility to mould their children into productive members of society. Children whose parents are more involved in their academics at home are likely to translate to productive and responsible members of society. According to the Children Act 2001 [1], children have a right to education which needs the support of parents to achieve. The best interest of the child must be presented at all times, and all actions and decisions made that affect them must be at their interest. This was also stipulated in the Education Act 2012 which stressed the importance of schools partnering with parents to ensure quality education and nurturing environment for children.

An effective form of involvement was presented by Epstein's model which described how children learn and develop through three overlapping "spheres of influence." These were: family, school and the community. These three spheres form a partnership to best meet the needs of the child. Epstein defines six types of involvement based on the relationship between family, school and the community wise parenting skills, communication, volunteering, learning at home, and decision making as well as collaborating with the community. Epstein (2002) cited in Bower and Griffin [3], emphasized that all of these six types of involvement must be included to have a successful partnership. Pupils who have support from the parents at home showed better performance at school, while students lacking support struggled with their academics [3].

\section{Literature Underpinning}

Seneschal and Young [4] conducted a meta-analysis to examine the relationship between parental involvement and the acquisition of literacy from kindergarten to third grade. The acquisition of literacy refers to the early literacy behaviour of children in grade $\mathrm{K}-3$. For the purpose of that Meta-analysis parental involvement was defined as parent-child home activities that were regarded to improve children's literacy. The involvement included parents' reading to children, parents listening to their children read and parents completing literacy exercise with their children. In order to determine a causal relationship between parental involvement and academic achievement, only studies that had quasi-experimental design were included in the selected 13 articles. The studies were conducted in Australia, the UK and in the United States of America. Overall results of this meta-analysis indicated that parental involvement positively influenced reading acquisition.

Jeynes[5] carried out a meta-analysis on parental participation in educational activities at home. The study targeted parents and sampled both fathers and mothers. Using interview schedule and questionnaire for data collection and eventual analysis by inferential statistics' ANOVA, the study findings showed a strong positive association between parental style defined as supportive, loving and helpful parents and maintaining an adequate level of discipline and 
academic achievement. These positive associations may be due to the ability of parents with an authoritative parenting style to be loving and supportive and yet maintain an adequate level of discipline in the household. Parents with this parenting style also demonstrate qualities such as trust and approachability that motivate children to discuss academic problems and expectations with their parents. Additionally, such parents are more likely to make contact with teachers when students have academic or behavioural problems.

Osei-Akodo, Chowa and Ansong[6] investigated the extent of parental involvement in academic performance in Ghana using randomized cluster sampling of 100 schools from eight out of ten regions. The results indicated that the majority of the parents (83\%) hardly assisted children in homework. In the same vein, Kimani [7] examined the level of parental involvement among standard three pupils reading at home and the influence of parental role construction. The study used descriptive research design guided by Hoover - Dempsey and Slanders model of parental involvement, complemented by Grolnicks theory of parental involvement. Descriptive and inferential statistics were used to summarize and analyze data. The chi-square test was used to test the null hypothesis at a significance level of 0.05 . Analysis of respondents from 137 parents randomly selected from both public and private schools in Igembe south revealed very low parental involvement in the modelling, cognitive and behavioural dimension of parental involvement. The study found that most of the parents had a low level of construct regarding their involvement in their children's reading at home.

Tarsilla and Ndirangu[8] conducted a study to investigate the influence of parental involvement in their children's academic achievement in public secondary schools: a case of Kieni-West Sub-County in Nyeri County- Kenya. This study was set to investigate the effects of parents' involvement in their children's academic achievement in twenty-one public secondary schools in Kieni West Sub-County. The objectives of the study were to: investigate the nature of parents' involvement in their children's academic achievement; establish to what extent factors influencing parental involvement contribute to their children's academic achievement, and investigate teachers' views about parents' involvement in the learners' academic achievement. Their study employed both qualitative and quantitative techniques in collecting and analyzing data collected from purposively sampled from three students. The study used two sets of instruments namely: questionnaire for teachers and students and a structured interview schedule for parents. The findings of the study indicated that $84.7 \%$ of the parents interviewed participated in school events and activities while $71.6 \%$ monitored homework. Parents' responses indicated that $92 \%$ believed that their involvement is beneficial to the teachers in aiding their children's educational progress. In addition, $98.2 \%$ felt that organized parental involvement programmes can improve their relationship with their children. Major recommendations included among others identifying the type of parental involvement in place, parent's awareness programmes through seminars and workshops and holding teacher parents conferences.

Chemagosi[9] conducted a study to investigate the influence of parental involvement on academic performance of pre-school children in Emgwen division, Nandi Central District, Kenya. The purpose of this study was to find out the influence of parental involvement on the academic performance of pre-school children in Emgwen Division, Nandi Central District, Kenya. The study's objectives were to: establish the influence of parental perceptions of involvement on academic performance of pre-school children; examine the influence of parental types of involvement on their children's academic performance; find out the influence of parental role of involvement on the pre-school children academic performance; determine the influence of parental initiative of involvement on preschool children academic performance; and establish the influence of parental time of involvement on academic performance of pre-school children. The study employed the use of descriptive research design. The target population comprised children, teachers and parents of pre-school children in Emgwen Division. The study adopted a simple random sampling technique to obtain a sample of 17 teachers in Emgwen Division.

Documentary analysis was provided by the teachers showing pre-school children academic performance in the Mathematics, Kiswahili and English activity areas. Questionnaire for the teachers was used for data collection. Reliability was ensured through test-retest method and validity was tested through a pilot study. The research utilized descriptive analysis and data was presented in the form of tables. From the data analyzed, the study noted the following findings; the majority of the respondents had good initiative towards their children's performance. Preschool children from parents with the good initiative performed better. Research findings are valuable to educationalists by helping them come up with better practices for incorporating parental involvement in academic affairs of pre-school children. Parents, teachers and all scholars, interested in education and factors affecting the 
performance of pre-school children, get to understand the influence of parental involvement on academic performance of pre-school children.

Kibet[10] investigated the role of parents in enhancing pre-school children's education in Uasin-Gishu District, Kenya and found that parental involvement in education was low. This study was however limited in scope covering only pre-primary schools. From Ciaraka[11], the research that sought to establish the role of parents in facilitating the learning processes in selected primary schools in Egoji- Meru found that parental involvement in homework was high but the majority (93\%) of the parents did not regularly check children's exercise books.

Tanui[12] reported that a large number of children who were having difficulties in their academic progress were not receiving adequate help at home. It appeared that fathers were not willing or were unavailable to devote much time to their children's academic performance. It is the duty of parents to spare much of their time to shoulder more responsibility towards their children's academic performance, even if it just means to supervise homework. Muola[13], on the other hand, summarized the activities that parents needed to spare time to engage their children in. These were home-related activities that encourage children's academic performance and they included: parents working with children on their home works; parents talking to children about school-related topics; and parents sparing time to take their children on field trips. Regarding the parental time of involvement on pre-school children's academic performance, the more time parents worked with their children on their homework, the more influence it had on their children's academic performance. Parents who motivated their children at most times and made follow up activities in school work, had their children performing better.

Muindi[14] also carried out a survey to find out what determines the performance of students at the end of the school cycle. The survey examined the children's personal, home and school profiles and how they supported and hindered learning. A total of 7931 pupils were interviewed in 328 primary schools in 76 districts countrywide. The study indicated that only $17 \%$ of fathers and $36 \%$ of mothers in Nairobi helped their children with homework. According to the study, the task of helping children with homework was left to siblings (46\%). The study also showed that more than $60 \%$ of parents were not taking a close interest in their children's homework. Majority of the pupils interviewed (88\%) admitted that they were given homework at school yet only half reported having been helped by their parents. The fathers were found not to be taking an interest in their children's homework. Wanja [15] expressed concern over the low numbers of fathers assisting their children with homework. She went further to say that fathers should know that their responsibility as fathers did not end at birth of their children but that it was their duty to take care and provide for their children till they became independent. It is upon the foregoing discourse that this study was deemed fundamental in examining the influence of parental participation in children's school activities on academic performance in primary schools in Ainabkoi Sub-County.

\section{Methodology}

The study adopted the ex-post facto design because the independent variable could not be directly manipulated. The use of this design in research has been supported by researchers such as Best and Khan [16] who supported the use of ex-post facto research design in analyzing past events or already existing conditions to study causation when it's impracticable or unethical to arrange occurrences. Furthermore, Nachimias and Nachimias [17] stated that ex-post facto research design is useful when trying to describe patterns of relationships between variables that cannot be manipulated, hence parents' involvement in their children's education at primary level as brought out in this study.

The study targeted primary schools whose population based on the data obtained from the County Education Office in October 2018, showed 61 public primary schools in the sub-county with a population of 2404 Class 8 pupils and 61 class teachers. The class teachers were selected as they are change agents for quality teaching and learning custodians of knowledge for pupils on behalf of parents. A sample size of 331 pupils was obtained using Krejcie and Morgan (1970) formulate and employed stratified simple random sampling technique while a census was considered for the teachers as all the 61 class teachers were included in the study. The sample distribution is as shown in Table 1. 
Table 1. Sample Distribution

\begin{tabular}{lll}
\hline Category of Respondents & Population & Sample Size \\
\hline Class Teachers & 61 & 61 \\
Pupil & 2404 & 331 \\
\hline Total & $\mathbf{2 4 6 5}$ & $\mathbf{3 9 2}$ \\
\hline
\end{tabular}

The data collection tools comprised questionnaires for the pupils given the large sample size [18] and teachers' interview schedule for which were structured in nature for clarification purposes [19]. The collected data was then analyzed both quantitatively and qualitatively. Quantitative data were analyzed using descriptive statistics and inferential statistics. The inferential statistics by use of chi-square test was conducted at $95 \%$ confidence level. While quantitative data were presented in tables and charts in the form of means, standard deviation, frequencies and percentages. Qualitative data was presented thematically.

\section{Results and Discussion}

The aim of the study was to determine the influence of parental participation in educational activities at home on Pupils' academic performance. Responses were sought from pupils on the relationship between the two variables under study and these are illustrated in Table 2. In achieving the study objective, the authors investigated whether the parents were schooled to a level they could participate in their children's homework. The findings draw on a 5 point Likert scale of Strongly Agree (SA), Agree (A), Undecided (U), Disagree (D), Strongly Disagree (SD) revealed that $28 \%$ of the pupils disagreed that their parents had schooled to a level they could participate in their homework, $13.4 \%$ of the pupils were undecided while majority $59.5 \%$ of them agreed that their parents had schooled to a level that they could participate in their homework.

The study also sought to investigate whether the parents gave the pupils guidelines on how to tackle their homework. The findings revealed that majority $(74.5 \%)$ of the parents gave their children guidelines on how to tackle homework, $5.6 \%$ were undecided while $15.9 \%$ disagreed indicating that their parents did not give them guidelines on how to tackle their homework. This indicated that the majority of the parents were educated, knowledgeable of the subject matter, and were willing to assist their children to tackle homework. This motivated the pupils to perform better academically. 
Table 2. Parental Participation in Educational Activities at Home and Pupils Academic Performance

\begin{tabular}{|c|c|c|c|c|c|c|c|}
\hline Statement & $\begin{array}{l}\text { SD } \\
\text { F }(\%)\end{array}$ & $\begin{array}{l}\text { D } \\
\text { F }(\%)\end{array}$ & $\begin{array}{l}\mathbf{U} \\
\mathbf{F}(\%)\end{array}$ & $\begin{array}{l}\mathbf{A} \\
\mathbf{F}(\%)\end{array}$ & $\begin{array}{l}\text { SA } \\
\text { F }(\%)\end{array}$ & Mean & S. Dev \\
\hline $\begin{array}{l}\text { My mother is schooled to a level that she can participate in my } \\
\text { homework }\end{array}$ & $53(16.2)$ & $39(11.8)$ & $44(13.4)$ & $94(28.3)$ & $100(30.2)$ & 3.45 & 1.44 \\
\hline My parents give me guidelines to tackle my homework & $32(9.7)$ & $34(10.3)$ & $18(5.6)$ & $121(36.8)$ & $124(37.7)$ & 3.60 & 1.41 \\
\hline $\begin{array}{l}\text { My parents encourage me to work on my homework by working on } \\
\text { my reading/writing duties alongside me }\end{array}$ & $53(16.2)$ & $42(12.8)$ & $46(14.0)$ & $99(29.9$ & $89(27.1)$ & 3.39 & 1.42 \\
\hline $\begin{array}{l}\text { My parents help me with homework because they want me to excel in } \\
\text { my education }\end{array}$ & $50(15.3)$ & $32(9.7)$ & $55(16.8)$ & $82(24.9)$ & $110(33.3)$ & 3.51 & 1.41 \\
\hline $\begin{array}{l}\text { My parents help me with homework so that I can be self-reliant in my } \\
\text { life }\end{array}$ & $54(16.5)$ & $29(8.7)$ & $57(17.4)$ & $91(27.7)$ & $98(29.6)$ & 3.45 & 1.42 \\
\hline Parent ensures I complete homework & $53(16.2)$ & $31(9.3)$ & $48(14.6)$ & $103(31.2)$ & $95(28.7$ & 3.4 & 1.41 \\
\hline Parent checks and signs completed homework & $94(28.3)$ & $36(10.9)$ & $54(16.5)$ & $93(28.3)$ & $52(15.9)$ & 2.93 & 1.47 \\
\hline Parent discusses with me the homework assigned & $55(16.8)$ & $31(9.3)$ & $60(18.1)$ & $99(29.9)$ & $84(25.9)$ & 3.39 & 1.40 \\
\hline Parent monitors me as I do the homework & $54(16.5)$ & $33(10.0)$ & $31(9.3)$ & $66(19.9)$ & $139(44.2)$ & 3.65 & 1.52 \\
\hline My parents/guardians get extra time for interaction at home or outside & $61(18.4)$ & $47(14.3)$ & $48(14.6)$ & $101(30.5)$ & $73(22.1)$ & 3.24 & 1.42 \\
\hline When I need assistance in any school work my parent attend promptly & $144(43.6)$ & $40(12.1)$ & $33(10.0)$ & $65(19.6)$ & $48(14.6)$ & 2.50 & 1.45 \\
\hline My parents/guardians are strict on proper use of leisure time at home & $61(18.4)$ & $48(14.3)$ & 48(14.6) & $101(30.5)$ & $73(22.1)$ & 3.24 & 1.42 \\
\hline My parents/guardians are strict on my peer groups' relationships & $144(43.6)$ & $40(12.1)$ & $33(10.0)$ & $65(19.6)$ & $48(14.6)$ & 2.50 & 1.45 \\
\hline My parents/guardians talk to me about what I am learning & $8(24.3)$ & $32(9.7)$ & 43(13.1) & $83(25.2)$ & $95(28.7)$ & 3.23 & 1.55 \\
\hline $\begin{array}{l}\text { My parents/guardians take me to the library, museums \& other } \\
\text { learning areas }\end{array}$ & $55(16.8)$ & $31(9.3)$ & $60(18.1)$ & $165(29.9)$ & $85(25.9)$ & 3.39 & 1.40 \\
\hline
\end{tabular}


The study also sought to investigate whether parents encouraged pupils to work on their homework by assisting with their reading/writing assignments. The findings indicated that $27 \%$ of the pupils disagreed, $14.0 \%$ were undecided while the majority $(57.0 \%)$ of the pupils agreed that their parents encouraged them to work on their homework by working alongside them. The findings indicated that the majority of the parents participate in their children's homework which contributed to their performance in school.

On whether parents helped their children with homework purposefully for them to excel, the majority (58.2\%) of the pupils agreed, $16.8 \%$ were undecided while $24.0 \%$ disagreed on their parents participating in their homework for them to excel. The findings thus indicate that the main reason why parents participate in their children's educational activities is that they want them to perform well in their academics. The authors then needed to understand if parents helped their children in homework so that they could be self-reliant in life and the findings revealed that majority $(57.3 \%)$ of the pupils agreed that their parents participated in their homework activities since they wanted them to be self-reliant in their life, $17.4 \%$ of the pupils were undecided while $25.2 \%$ of the pupils disagreed that the reason why their parents participate in their homework was because they wanted them to be self-reliant in life.

In addition, the study investigated whether parents ensured that pupils completed their homework. The findings showed that $59.9 \%$ of the pupils agreed, $14.6 \%$ of the students were undecided while $25.5 \%$ of the pupils disagreed that their parents ensured that they completed their homework. After completion, it was found that most parents checked and signed completed homework by their children, $16.5 \%$ were undecided while $15.9 \%$ of the pupils agreed that their parents checked and signed their homework. The findings also revealed that majority (55.8\%) of the pupils agreed that their parents discussed with them their assigned homework, $18.1 \%$ were undecided while $26.1 \%$ of the pupils disagreed that their parents discussed with them the assigned homework.

Monitoring of pupils while they undertake their studies is key to ensuring that the assignments are undertaken as depicted in this study. It was established that the majority of the pupils agreed that their parents monitored them as they did their homework. At least $9.3 \%$ of the pupils were undecided while $26.5 \%$ of the students disagreed that their parents monitored them as they did their homework. On whether the parents/guardians got extra time for interaction with their children at home or outside to guide them on educational activities, the findings indicated that majority $52.6 \%$ of the pupils agreed that their parents organized to interact with them on educational activities at home and outside home, $14.6 \%$ were undecided while $28.9 \%$ of the pupils disagreed that their parents interacted with them on educational activities at home. More so, pupils were not assisted by their parents in school work as depicted by the majority who disagreed with the statement that their parents assisted them in school work. At least $10.0 \%$ were undecided while only $24.2 \%$ of the pupils agreed that their parents assisted them in school work. However most $53.9 \%$ of the pupils agreed that their parents/ guardians encouraged them to work hard in school, $13.1 \%$ were undecided while $22.8 \%$ of the pupils disagreed that their parents encourage them to work hard in school.

Another section of pupils (52.6\%)majorly indicated that their parents were strict on how they spent their leisure time, $14.6 \%$ of the pupils were undecided while $28.9 \%$ of the pupils disagreed that their parents were strict on how they spent their leisure time. On the other hand, the majority (55.7\%) of the pupils disagreed that their parents were strict on their peer relationships, $10.0 \%$ were undecided while $33.2 \%$ of the pupils agreed that their parents were strict on their peer relationships. The study also sought answers on whether the parents/ guardians took the children to libraries, museums and other learning areas, majority (55.9\%) of the pupils disagreed that the parents took them to learning institutions, $18.1 \%$ were undecided while $26.1 \%$ of the students agreed that their parents took them to libraries and learning institutions for them to gain insight on how to perform well in their education. The findings depicted in Table 2, therefore, imply that an increase in parental support at home for children by parents often improves their academic achievement in schools. The findings are consistent with Eamon [20] who reported that supportive and attentive parenting practices positively affect academic achievement in United States of America schools thus indicating that parents whether in developed or developing countries need to support their children in order to improve their performance.

To confirm the significance of the study results, a chi-square was computed at $95 \%$ confidence level. The results are illustrated in Table 3. 
Decision rule: If p-value is less than or equal to 0.05 reject the Null hypothesis. If $\mathrm{p}$-value is greater than 0.05 do not reject the Null hypothesis.

Table 3. Chi-Square Test

\begin{tabular}{llll}
\hline & Value & df & Asymp. Sig. (2-sided) \\
\hline Pearson Chi-Square & 8.196 & 2 & .017 \\
Likelihood Ratio & 8.012 & 2 & .018 \\
Linear-by-Linear Association & 4.036 & 1 & .045 \\
\hline N of Valid Cases & $\mathbf{3 3 0}$ & & \\
\hline
\end{tabular}

The null hypothesis tested stated that; parental participation in educational activities at home has no significant relationship with pupils' academic performance. The results as shown in Table 3 indicate the values of $\left(X^{2}=8.196\right.$, $\mathrm{df}=2$ ) and $\mathrm{p}=0.017$ which is less than the level of significance 0.05 . The null hypothesis was therefore rejected concluding that there exists a significant relationship ( $>0.05)$ between the parental participation in educational activities at home and pupils academic performance. This implies that children from families where the parents participated in their homework, are strict on peer relationship and provided their children with the required materials to learn, tend to perform well compared to those whose parents do not participate in their educational activities at home. Parents should therefore actively take part in their children's educational activities to help improve their academic performance.

The findings are consistent with Seneschal and Young (2008) meta-analysis on the relationship between parental involvement and the acquisition of literacy from Kindergarten to third grade. The study established parental involvement in reading listening to their children read and parents completing literacy exercise with their children improved the children literacy level. Overall results of this meta-analysis indicated that parental involvement positively influenced reading acquisition.

The findings also supported Jeynes [4] who carried out a meta-analysis study on parental participation in educational activities at home. The findings showed a strong positive association between parental style defined as supportive, loving, helpful, and maintaining an adequate level of discipline and academic achievement. These positive associations may be due to the ability of parents with an authoritative parenting style to be loving and supportive and yet maintain an adequate level of discipline in the household. Parents with this parenting style also demonstrate qualities such as trust and approachability that motivate children to discuss academic problems and expectations with their parents. Additionally, such parents are more likely to make contact with teachers when students have academic or behavioural problems.

Some inconsistencies were however established in this study in comparison to Osei-Akodo, et al [6] whose study on parental involvement in academic performance in Ghana established that majority of the parents (83\%) hardly assisted children in homework. Kimani [7] on the other hand in his study on parental involvement among standard three pupils' reading at home and the influence of parental role construction, found out that there was a very low parental involvement in the modelling, cognitive and behavioural dimension of their children. Most of the parents had a low level construct regarding their involvement in their children's reading at home.

The current study also is consistent with Tarsilla and Ndirangu's[8] study on the influence of parental involvement in their children's academic achievement in public secondary schools: a case of Kieni-West Sub-County, Nyeri County- Kenya. The findings of the study indicated that $84.7 \%$ of the parents interviewed participated in school events and activities while $71.6 \%$ monitored homework. Parents' responses indicated that $92 \%$ believed that their involvement is beneficial to the teachers in aiding in their children's educational progress. In addition, $98.2 \%$ felt that organized parental involvement programmes can improve their relationship with their children.

The findings were also in tandem with Chemagosi's [9] study on the influence of parental involvement on academic performance of pre-school children in Emgwen division, Nandi Central District, Kenya. The study established that majority of the respondents had good initiative towards their children's performance. Preschool children from parents with the good initiative performed better. Majority of the respondents indicated that sometimes they 
communicate with their pre-school children about their school progress. It was showed that children whose parents communicate with them perform better in academics than those who do not.

The findings were however inconsistent with Tanui's [11] study which reported that a large number of children who were having difficulties in their academic progress were not receiving adequate help at home. The study established that the fathers were not willing or were unavailable to devote much time to their children's academic performance. The findings were also inconsistent with Muindi's[13]survey which sought to find out what determines the performance of students at the end of the school cycle. The study indicated that only $17 \%$ of fathers and $36 \%$ of mothers in Nairobi helped their children with homework. According to Muindi's study, the responsibility of helping children with homework was left to siblings (46\%) and that more than $60 \%$ of parents were not taking a close interest in their children's homework [13].

\section{Conclusion}

The study concludes that children from families in which parents are involved in their homework, are strict on peer relationship and provide their children with the required materials to learn usually perform well compared to those whose parents who do not participate in their educational activities at home. The study, therefore, concluded that parental participation in educational activities at home had a significant relationship with pupils' academic performance.

\section{Recommendations}

Parental involvement in school activities should be encouraged, especially in the provision of supplementary reading materials. This influences the academic performance of pupils.

Many parents may not be aware of the requirement for them to participate in the learning process of their children hence parents should be informed that they can contribute to the academic achievement of their children through taking part and supporting their children while at home.

\section{References}

[1]. G.O.K, (2010).Kenya Gazette Supplement No 8: The Children's Act 2010 (141). Nairobi: Government Printers

[2]. G.O.K, (2012). Education Act (2012): Parental involvement in pupil education. Nairobi: Government Printers.

[3]. Bower, H. A., \& Griffin, D. (2011). Can the Epstein model of parental involvement work in a high - minority, high poverty elementary school? A case study. Professional School counselling, 15(2), 77-87

[4]. Senechal, M., \&Laura, Y.(2008). The Effect of Family Literacy Interventions on Children's Acquisition of Reading from Kindergarten to Grade 3: A meta-analytical Review. Review of Educational Research 78(4),880 - 907.

[5]. Jeynes, W. H. (2007). Parental Involvement and Student Achievement: A Meta-Analysis. Downloaded from: http://www.hfrp.org/publications. Resources/browse our publications /parental-involvement-and-student achievementa-meta-analysis.

[6]. Osei-Akodo, I., Chowa, G. \&Ansong, D. (2012).Parental involvement and academic performance in Ghana. Youth save Research Brief, CSD publication No. 12-42.

[7]. Kimani, H. K. (2014). Parental Involvement in Primary standard Three Pupils' reading at home in Igembe South Constituency Meru County, Kenya. Unpublished (Masters Thesis), Kenyatta University, Kenya.

[8]. Tarsilla, M. \&Ndirangu, L. M.(2014) Parental involvement in their children's Academic Achievement in public Secondary Schools.International Journal of Education and Research 2 (November 2014).

[9]. Chemagosi M. J. (2012).Influence of parental involvement on academic performance of preschool children. (Master's Thesis) University of Nairobi, Kenya.

[10]. Kibet, K. P. (2010). Teacher-parent partnership for enhancing quality in pre-school education: A case study of UasinGishu district, Kenya (PhD thesis) Kenyatta University. Nairobi.

[11]. Ciaraka, M. (2003). Parental Involvement in Facilitating the Learning Process: A case Study of Standard Eight Pupils in Selected Schools of Egoji-Meru, Kenya (Masters' project) Kenyatta University.

[12]. Tanui, K. (24 ${ }^{\text {th }}$ August 2011).Standard Newspaper, www.standardmedia.co.ke. Standard Group Center, Kenya.

[13]. Muola, J. M. (2010). A study of the relationship between academic achievement motivation and home environment among standard eight pupils, Educational Research and Reviews 5 (5), 213-217.

[14]. Muindi, K. K., \&Twoli, M.(2010).Instructional Methods in Education, (unpublished module) Kenyatta University.

[15]. Wanja, J. (22nd June 2010). Fathers and homework "are a Mess". Daily Nation. p. 3.

[16]. Best, W. J.\& Khan, J .U. (2003).Research methods in Education ( $7^{\text {th }}$ Edition). New Delhi Prentice Hall.

[17]. Nachmias, C. F., N \&Nachmias, D. (1996). Research Methods in the Social Sciences. London: St. Martins Press Inc.

[18]. Kombo, D. \& Tromp, D. (2006).Proposal and Thesis Writing: An Introduction. Nairobi: Pauline's Publication Africa. 
[19]. David, M. \& Sutton C. D. (2004).Social Research the Basics. London. SAGE Publications.

[20]. Eamon, M.K (2005). Social - Demographic, school Neighbourhood and parenting influences on Academic Achievement of Latino Young Adolescents. Journal of youth and Adolescent 34(2), 163 - 175. 